\title{
Angiomatosis peneana en paciente con Síndrome de Klippel-trenaunay
}

\author{
Rodríguez Corchero J, Álamo Martínez JMª, Congregado Ruiz CB, Conde Sánchez M, \\ Pérez Pérez M, Medina López R.
}

Servicio de Urología. Hospital Universitario Virgen del Rocío. Sevilla.

Actas Urol Esp. 2007;31(3):295

$\mathrm{P}$ aciente de 45 años, sin antecedentes personales de interés que acude a urgencias por hemorragia digestiva baja y discreta hematuria.

A la exploración se objetiva dismetría de miembros inferiores (Fig. 1) y varicosidades peneanas (Fig. 2). Se realiza colonoscopia y estudio angiográfico completo en los que se aprecia una angiomatosis mesentérica masiva.

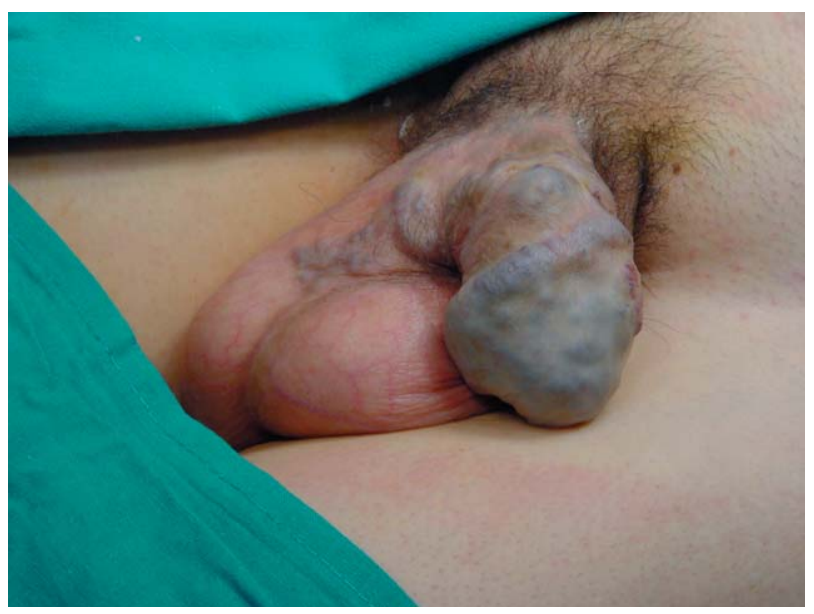

FIGURA 1

La laparotomía exploradora confirma los hallazgos descritos, objetivándose una angiomatosis mesentérica y mesocólica total que incluye los vasos pélvicos, haciendo el proceso patológico irresecable. El paciente fallece a los pocos meses por hemorragia digestiva masiva.

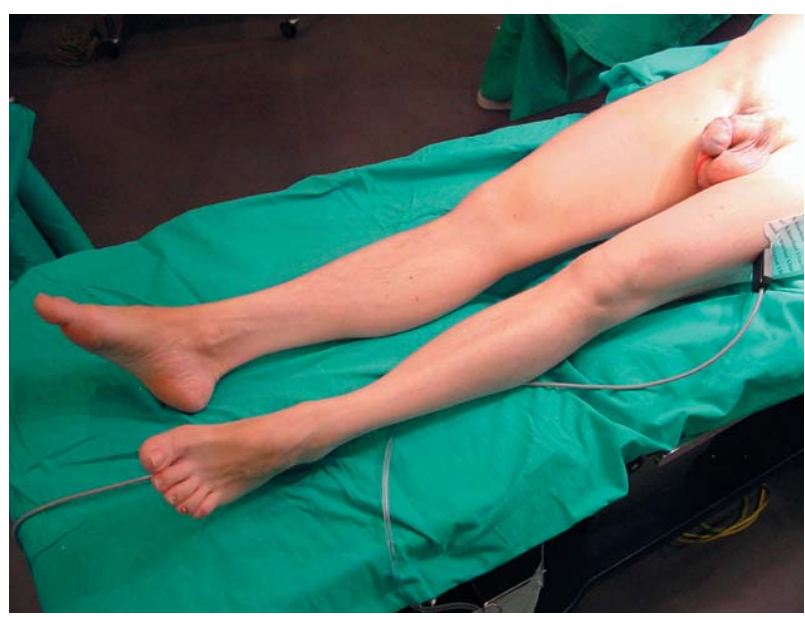

FIGURA 2

El paciente es finalmente diagnosticado de Síndrome de Klippel-Trenaunay-Weber descrito como un trastorno mesodérmico congénito raro que comprende la triada de hemangiomas, varicosidades e hipertrofia asimétrica de miembros inferiores, secundaria a la vascularización anómala congénita. La angiomatosis peneana es un hallazgo infrecuente, aunque descrito en este sindrome.

Correspondencia autor: Dr. Javier Rodríguez Corchero

Servicio de Urología. Hospital Infanta Elena

Ctra. Sevilla-Huelva, s/n. 21080 Huelva

Tel. 959015100

E-mail: jrcorchero@hotmail.com

Información artículo: Imágenes en Urología

Trabajo recibido: enero 2006

Trabajo aceptado: febrero 2006 